Adrienn Vida

Csaba Bálint Illés

\title{
2.5. MICROECONOMIC APPROACH OF BIOMASS USE OPTIMIZATION IN HUNGARY
}

\begin{abstract}
Summary
The use of renewable energy sources has been an important topic of scientific researches and many studies since the first energy crisis (1973) in different aspects through either specific or complex examinations. Until the beginning of the $21^{\text {st }}$ century, national and international objectives were focused on the use of different types of renewable energy sources (i.e. solar, wind, geothermal and biomass energy) without any limits, but nowadays the utilization of sustainable potential in a complex way - considering economic, ecologic and social aspects has been come to the front.

Our present research deals with the renewable energy sources of agricultural origin - i.e. the biomass energy - so it is essential to examine what is the exact role of agricultural production in energy production and how the different energy sources can be utilized.

The research examines the profitability of the sustainable production of renewable energy sources at farm level. In our research, in the production of primary products the minimizing of chemicals, while in the course of manufacturing process the minimizing of $\mathrm{CO}_{2}$ emission and water use were taken into consideration as sustainability aspects.

For the verification of our hypotheses two methods, life-cycle analysis (LCA) and pivot table were used.
\end{abstract}

Keywords: biomass, agriculture, renewable energy sources, life-cycle analysis, pivot programming

\section{Introduction}

The use of renewable energy sources has been an important topic of researches and scientific publications since the first energy crisis (see Barótfi, 1993; Stróbl, 2000; Hancsók, 2004; Ivelics, 2005), in which the different types of renewable energy sources were discussed in many aspects either separately or in a complex way.

The actuality of the use of biomass energy became very intensive in the past few years, but it has been important since the 1990s, and its importance increased significantly in the past years. The Europe 2020 strategy, the strategic document for the next decade that summarizes the most important directions for the EU, determined five headline targets which global importance is growing currently and shall be growing in the nearest future. One of them "Climate action and energy policy" focuses on reducing greenhouse gas emissions by 20 per cent compared to 1990, increasing the rate of renewable energies to 20 per cent in the whole of energy consumption. In order to fulfil the strategic goals, three priorities are put forward in the Strategy, from which "Sustainable growth" is for promoting a more resource efficient, greener and more 
Vida, A. - Illés, B. Cs.

competitive economy. (Törö-Dunay, 2011) The examination and evaluation of this topic was started by calculating the potential of renewable energy sources and by determining different scenarios for the future (see for example Láng et al., 1985; Lukács, 2009; Pylon, 2010; Greenpeace, 2011). Nevertheless, it is important to refer to that how the results of these examinations are connected to the categories of renewable energy sources in the international literature.

The concept given by Figure 1, is based on the principles of economic value of natural resources, considering the main aspects of environmental economics. The classical aspects of environmental economics consider the human values as the initial point, but in case of renewable energy sources, the non-human values are also important. Some authors do not classify the "Value of options" group into the "Utilization value", their place is depending on the initial base of classification. When we classify the values according to the utilization options of the natural resources, the "Value of options" group shall be connected to the "Value of origin". If we make the classification based on the prevention of natural resources or the costs of prevention, then the "Value of options" should be connected to the "Non-utilization value" group.

Figure 1: Economic structure of renewable energy sources

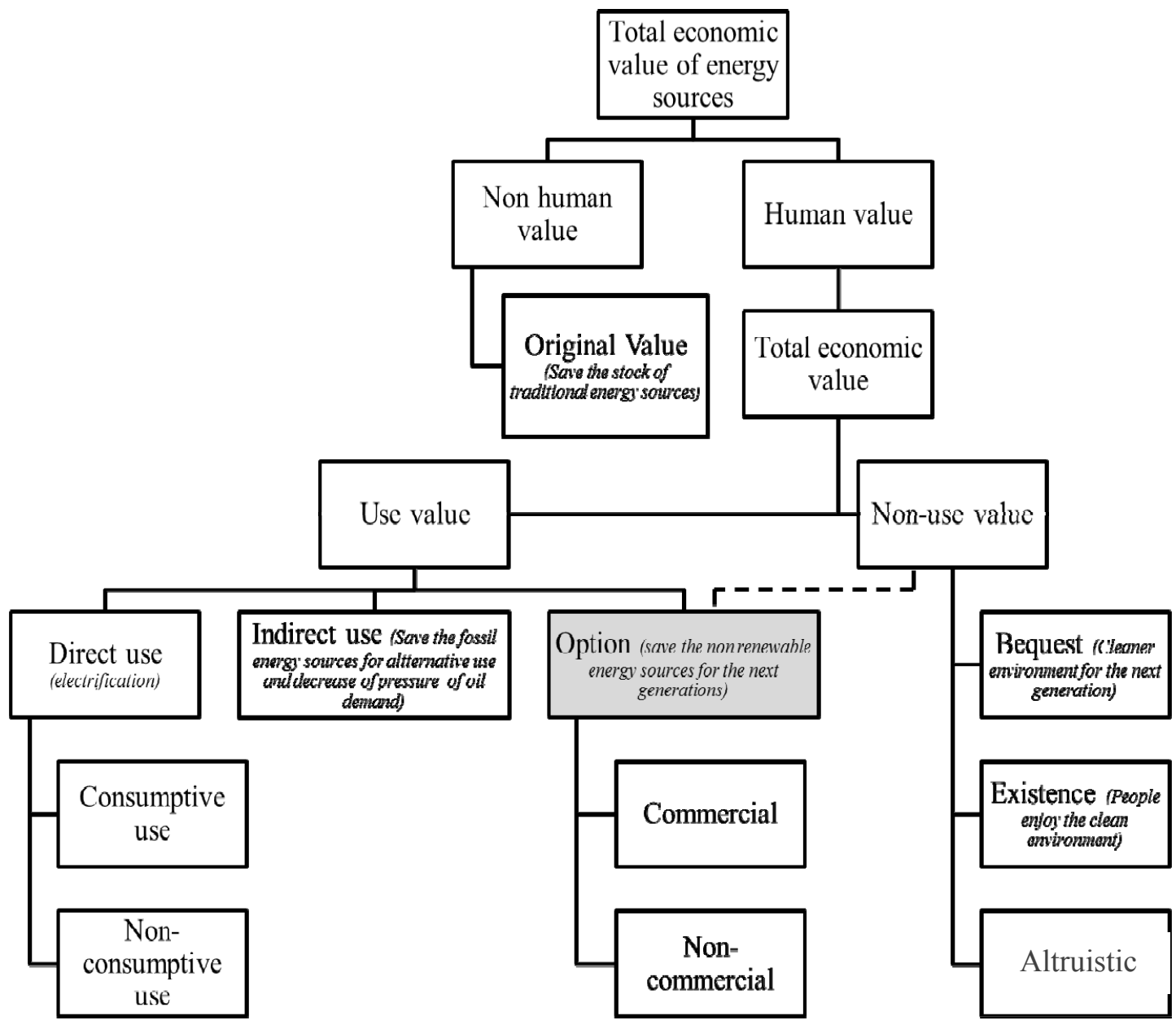

Source: Own construction (2013) based on Menegaki (2008. p. 2244.) and Szlávik (2006) 
In that case, when the ultimate goal of a research is to evaluate the financial value of natural resources, then the "Value of options" category will mean a transition stage or a link between the two main groups. The macroeconomic evaluation of renewable energy sources gives another aspect of the assessment of the possible solutions. Figure 2 illustrates the hierarchy of the potential of renewable energy sources according to the Hungarian Academy of Science.

As it is shown, the broadest category is the theoretical regional potential, in which determination no constraints are taken into consideration, only the real or the potential energy producing capacity of the different regions is taken into account. When some constraints (such as the change of the production yields in some sectors, or the production for food supply) are given, then the convertible potential can be calculated.

After optimization of technical and the economic factors, we can determine the technical and the efficient potentials. The narrowest category is sustainable potential, which includes the ecologic, economic and social aspects and requirements, i.e. the most important criteria of long-term use.

Figure 1: The hierarchy of the potential of renewable energy sources

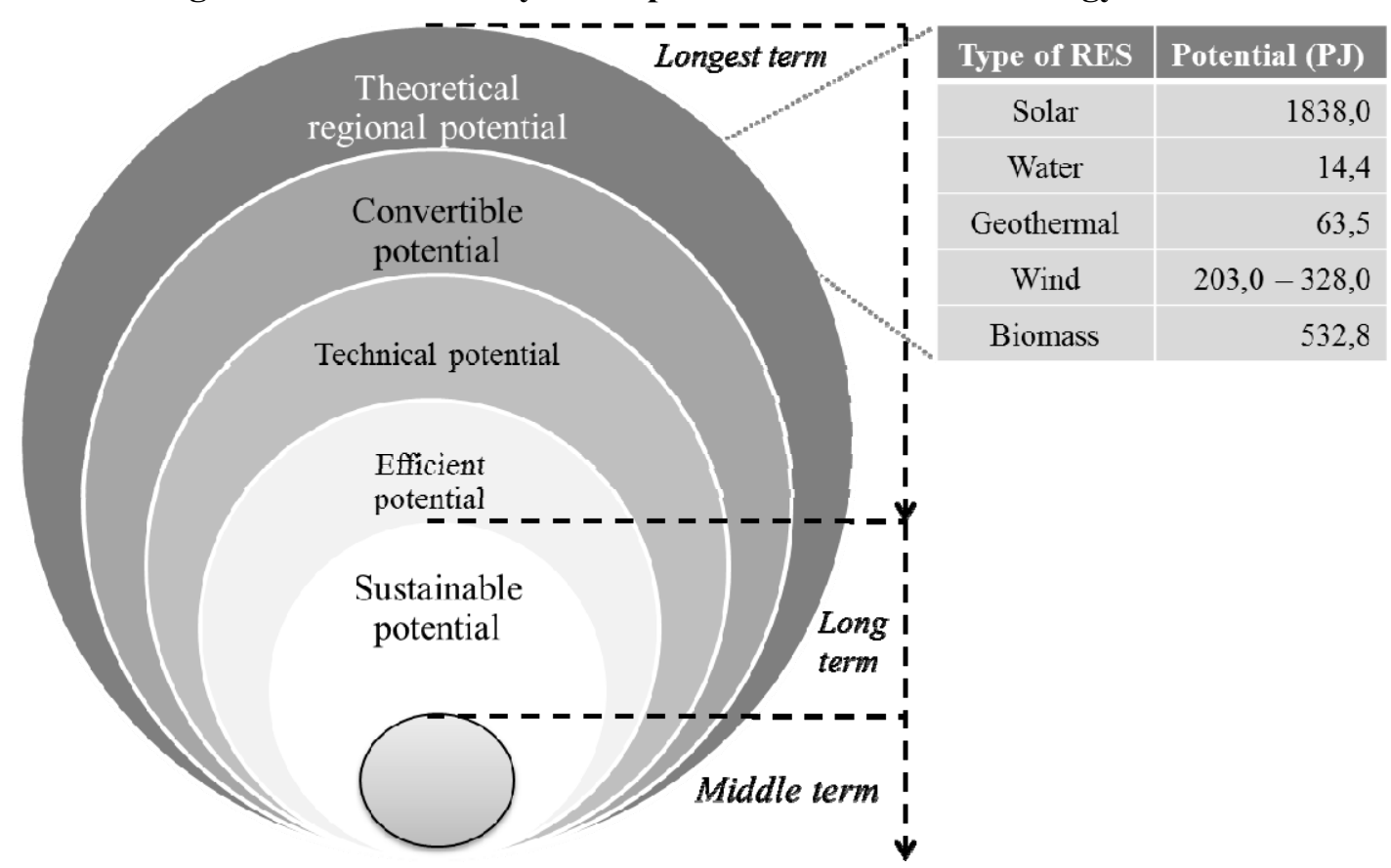

Source: Own construction, 2013 on Pylon, 2010, 72. p., Hungarian Strategy (2008), Hungarian Action Plan (2010)

The well-known "long-term" use shall be considered only as a general term. As it is illustrated by Figure 2, the use of renewable energy sources may be differentiated according to the length of time focusing on the different potential values. The "longest" period is about 50 years long, which refers to the possible potentials that are based on calculations with long-term data. "Sustainable potential" is for 15-20 years period, which is used in EU and national policies. A smaller part of this period is medium term period, which means the potential that may be realized within 5-10 
Vida, A. - Illés, B. Cs.

years. This period may refer to the feasibility of long-term strategies, and in within this period the threats and the opportunities at macroeconomic level may also become clear. The narrowest category is sustainable potential, which includes the ecologic, economic and social aspects as the main criteria of the long-term use of these resources.

In addition to defining the different categories of renewable energy sources, it is also important to introduce the quantifiable data of the different potentials. Table 1 summarizes the most recent calculations made by governmental and EU institutions and different NGOs.

Table 1: Different calculations of Potential of Renewable Energy Sources (RES) in Hungary

\begin{tabular}{|c|c|c|c|c|c|}
\hline \multirow{2}{*}{ Type of RES } & \multirow{2}{*}{$\begin{array}{c}\text { Used RES } \\
\text { in } 2005 \\
\text { (PJ) }\end{array}$} & \multirow{2}{*}{$\begin{array}{c}\text { Sustainable potential } \\
\text { to } 2020 \text { (PJ) } \\
\text { Calculations of Pylon } \\
\text { Ltd. }\end{array}$} & \multicolumn{2}{|c|}{$\begin{array}{c}\text { Hungarian Strategy to } \\
2020(\mathrm{PJ})\end{array}$} & \multirow{2}{*}{$\begin{array}{c}\text { Calculations } \\
\text { of Energy } \\
\text { Club to } 2020 \\
\text { (PJ) } \\
\end{array}$} \\
\hline & & & BAU Plan & $\begin{array}{l}\text { "Policy" } \\
\text { Plan }\end{array}$ & \\
\hline Wind energy & 0,04 & 15,50 & 4,00 & 6,10 & 6,30 \\
\hline Solar energy & 0,08 & 22,00 & 0,40 & 1,70 & 2,00 \\
\hline Water energy & 0,73 & 2,30 & 0,90 & 0,90 & 1,20 \\
\hline $\begin{array}{l}\text { Geotermal } \\
\text { energy }\end{array}$ & 3,63 & 29,30 & 7,30 & 11,40 & 20,00 \\
\hline Solid biomas & 43,56 & 150,00 & 93,70 & 130,90 & 143,90 \\
\hline Biogas & 0,30 & 13,20 & 6,80 & 12,50 & 15,00 \\
\hline Biofuels & 0,21 & $\begin{array}{c}\text { (calculated in solid } \\
\text { biomass) }\end{array}$ & 19,60 & 19,50 & 12,90 \\
\hline $\begin{array}{l}\text { Common } \\
\text { waste }\end{array}$ & 1,38 & 4,30 & 3,30 & 3,40 & 3,30 \\
\hline Total & 49,93 & 221,10 & 136,00 & 186,40 & 204,60 \\
\hline
\end{tabular}

Legend: BAU: Business as Usual

Source: Own construction, 2013 on Hungarian Strategy (2008), Hungarian Action Plan (2010) and Pylon Ltd. (2010)

As it is shown in the Table 1, there are significant differences between the results of various Hungarian calculations. In this regard, it is important to note that the paper of Pylon Ltd. focused on those renewable energy sources which are used for electricity production. That is why the wind and solar energy significantly, while geothermal energy is slightly over-represented. The slight difference between the two biofuel scenarios given by the Hungarian Strategy for Increasing of Use of Renewable Energy Sources between 2008 and 2020 is due to the compulsory blending ratio of fuels. The compulsory blending ratio of fuels is the only type of renewable energy source which is obligatory in all Member States.

This paper deals with the renewable energy sources of agricultural origin, namely biomass energy, therefore, at first we have to determine the role of agricultural production in energy production, how agriculture can influence energy production processes, and how and to which extent it can utilize different energy sources. 
Based on the European Energy Association estimates, agriculture and organic waste can provide significant portion of the biomass potential in Hungary (projected for energy content - see Figure 3.). The role of the forest sector both in relative and absolute terms is extremely low because of the stringent legal background. A further consideration regarding potential expansion of (energetical) short rotation wood plantations is the soil requirements (except for a few hybrids) which is similar to the traditional fieldcrops. Another problem of farmers that energy plantations need the long-term use of the soil, therefore the inflexibility of this cropping method reduces the potential of growth.

Figure 3: Potential of agricultural biomass from international point of view

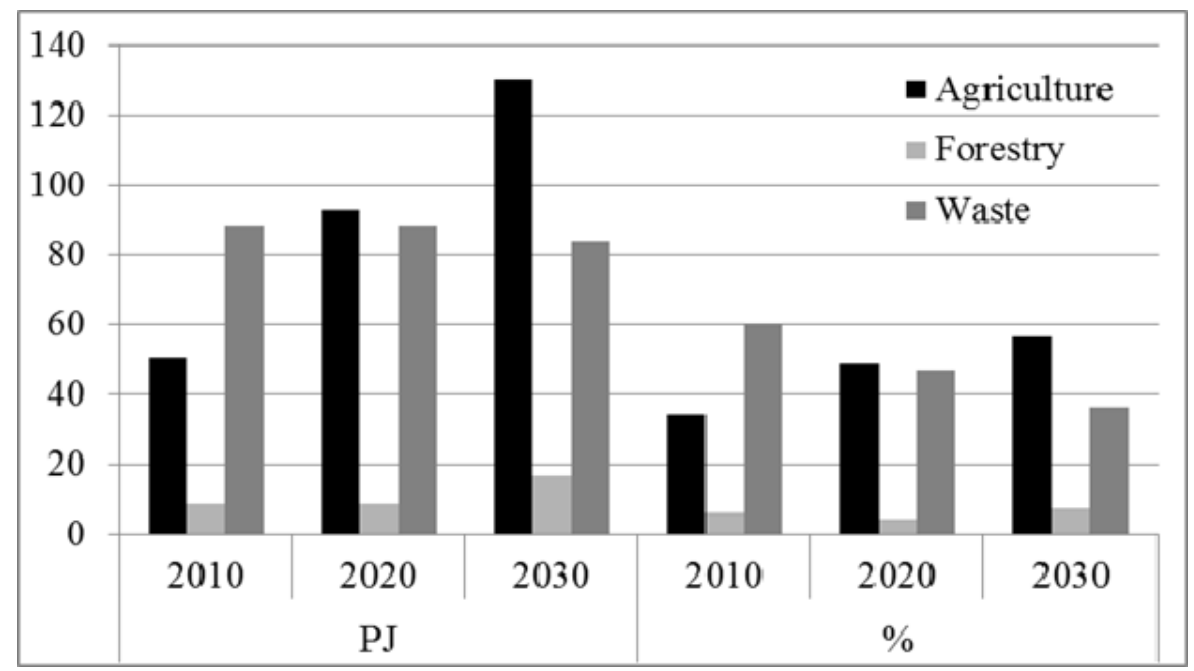

Source: EEA, 2007

Büki (2007) examined the topic from another aspect, namely the relative nominal energy consumption of biomass production. According his calculations, the natural forests have the smallest role, the energy grasses is preferred in case of energy plants, while in case of biofuels, wheat and oilseed rape are preferred.

Agriculture is both the producer and the user of different energy sources (Ángyán et al., 2006). Due to the different types of support, the volume and the composition of agricultural investments have been fluctuating for the past years. The development and investments for energetic objectives represented only $1 \%$ of the agricultural investments in 2011 (AKI, 2012). This fact is in accordance with the opinion of Brochers et al. (2008), which implies that the energetic developments in the agricultural sector are realized in an indirect way, not as a specific intent.

In our research in addition to the economic aspects of biomass energy production, we focused on the technical and environmental effects, and made our examinations in accordance with these three pillars. The theoretical base and the structure of our researches are illustrated by Figure 4. 
Vida, A. - Illés, B. Cs.

Figure 4: Theoretical aspects of the microeconomic (farm-level) assessment of renewable energy sources of agricultural origin

\begin{tabular}{|c|c|c|}
\hline $\mathrm{CO}_{2}$ saving or emission & Water (re)use & Energy need \\
\hline \multicolumn{3}{|c|}{ Environment (positive or negative) effect } \\
\hline
\end{tabular}

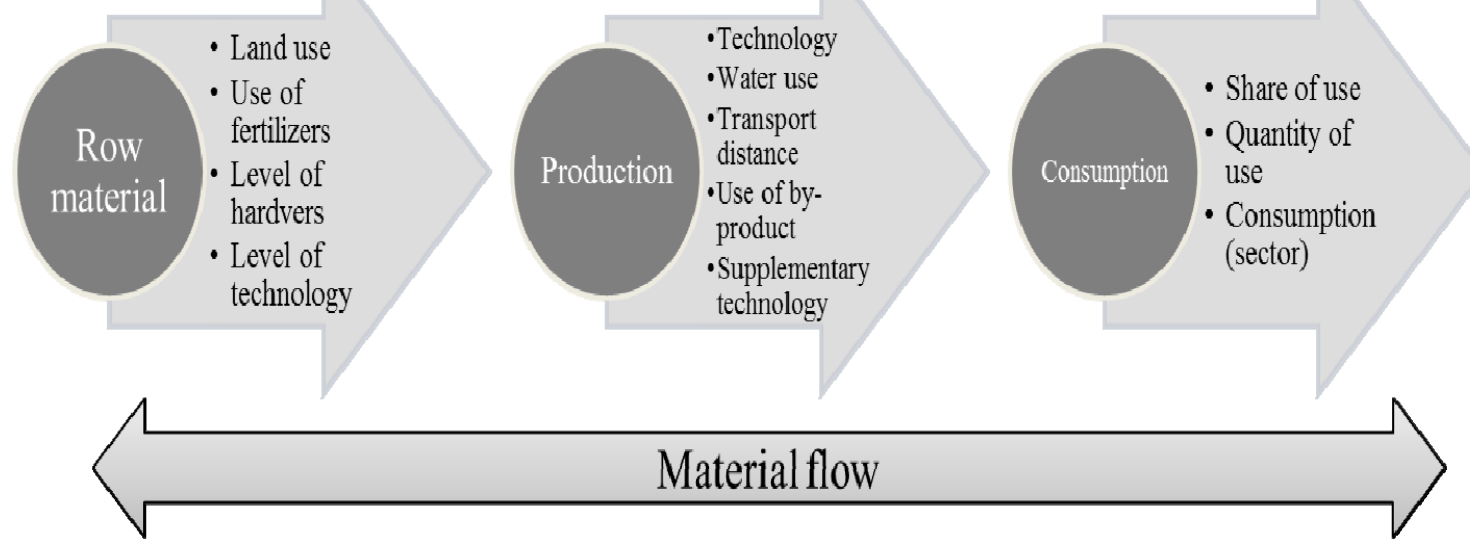

Source: Own construction, 2012

In one hand, the process takes into account the structure of the production and in the other hand, it is also considers the positive or negative environmental impacts associated with each step. Throughout the entire production process of biomass material flow, the direction of the process is not unequivocal because the different by-products can be utilized not only in the given stage of the process but also in other (previous) stages. For example, the by-products of energy crops can be utilized in animal husbandry or the by-product of bioethanol - it is called DDG (Dried Distillers Grain) - can be used as fodder or may be the raw material of biogas production. This process-oriented logic frame is able to examine the effects and their resources and it is also able to explore the critical factors and to improve efficiency through a detailed analysis of the technological background. (Illés et al., 2013)

The first step of the process is biomass production, which may be a result of an intended process with direct energetic objectives, or, it can be derived from the crop production with food producing purposes as a by-product, and even from livestock production in the form of liquid or solid manure. When we examine the biomass producing processes of crop production (cereals, oilseeds or energy forests) the most important aspect is to evaluate the different features of production. For example, In Hungary, the structure of crop production and land use has not been changed because of the production of renewable energy sources, as it is more typical to use the surpluses of food cereals through the channels of energy industry.

The positive and negative environmental effects of the used energy resources may be determined by the following conditions: (Ericsson et al., 2009)

-the effectiveness of the technology,

-the amount and quality of the chemicals used during the production process, 
-the technology and intensity of production,

- level of water use.

The level of possible ethanol production may be an additional important determining factor of the environmental effects (see Figure 5).

Figure 5: The carbohydrate ratios and ethanol yields of the raw materials of bioethanol production

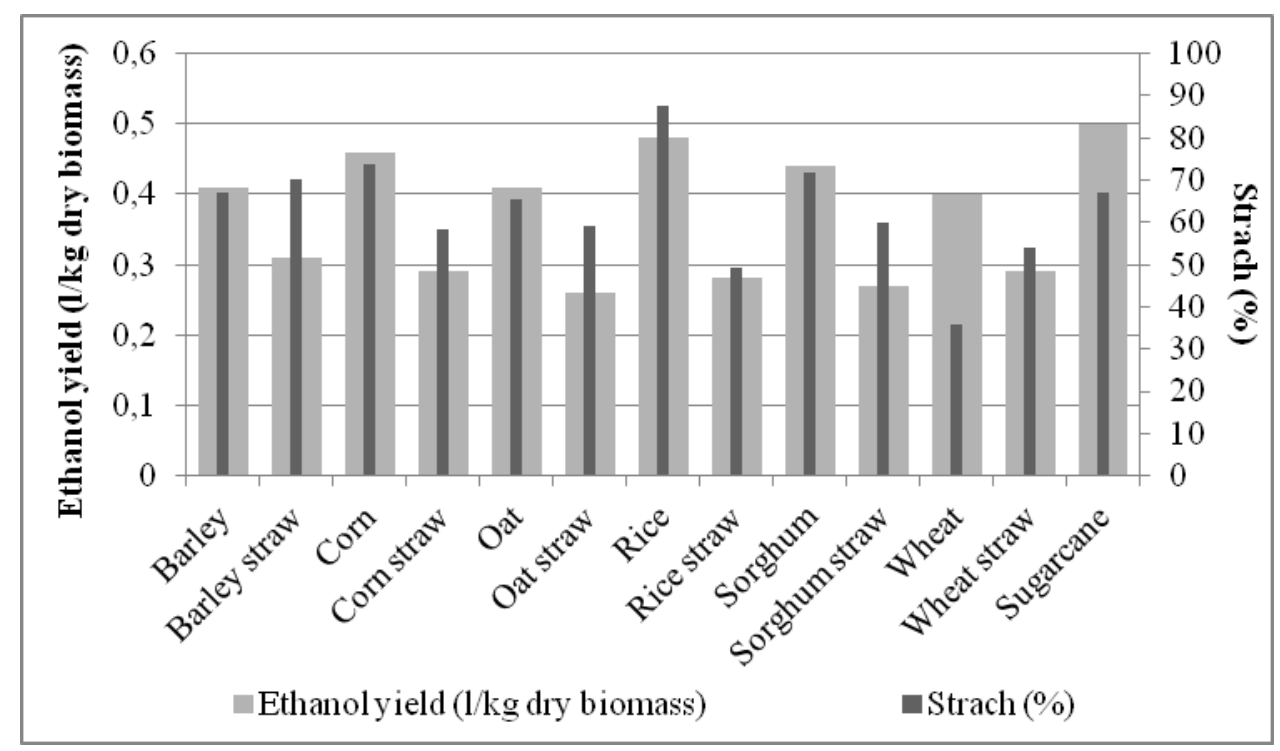

Source: Own construction (2012) based on Boros (2007)

Although some authors formulated different opinions in connection with the possible effects of chemicals, the technological level and the costs of production on the biomass energy production and also the cost structure of crop production should be taken into consideration during the optimization process.

\section{Material and methods}

Life cycle Analysis (LCA) is a widely used (strategic) decision supporting tool for both the corporate and governmental sectors. It is most often used for the following purposes:

- preparation or/and planning of product development and/or improvement,

- to distinguish products and services for marketing purposes,

- to analyze materials, energy and emission processes of production or service processes,

- comparison of alternative production processes, services,

- calculation of input/output ratios and/or efficiency analysis,

- critical point analysis for exploration of possible reduction of emissions or energy saving,

- preparation of policy strategies or legislation and planning of the possible effects of these policies,

- calculation of environmental charges and fees or the level of penalties. 
Vida, A. - Illés, B. Cs.

The LCA is used in those industrial areas where the natural environment is used intensively or which actions have considerable effects on the natural environment (e.g. waste management, energy or heavy industry).

Before the calculations, it may be necessary to define certain regularities and terms by which the whole method may be simplified. One of the most difficult questions of the LCA is to define those factors and effects which should be taken into account in the assessment. The so-called cut-off rule allows that only the relevant elements can be taken into account in the LCA process. The decision maker must determine that certain threshold, over or under which an effect is leaved disregarded. The advantage of this rule is to make the process cheaper but its threat is worsening the reliability of the results. The sharing or allocation rule allows the solution of those problems when through a (sub)process multiple products or by-products are made, but there is only the overall effect or the whole material flow is known. In this case, the total effect should be allocated on the basis of the physical characteristics of the product(s) or the by-product(s). For the more reliable results, it is suggested to load the method with different partition of the characteristics and to compare the different results of sensitivity analysis. The first step of the whole process is the inventory analysis, at it is shown by the Figure 6.

Figure 6: Standardized process of Life Cycle Analysis

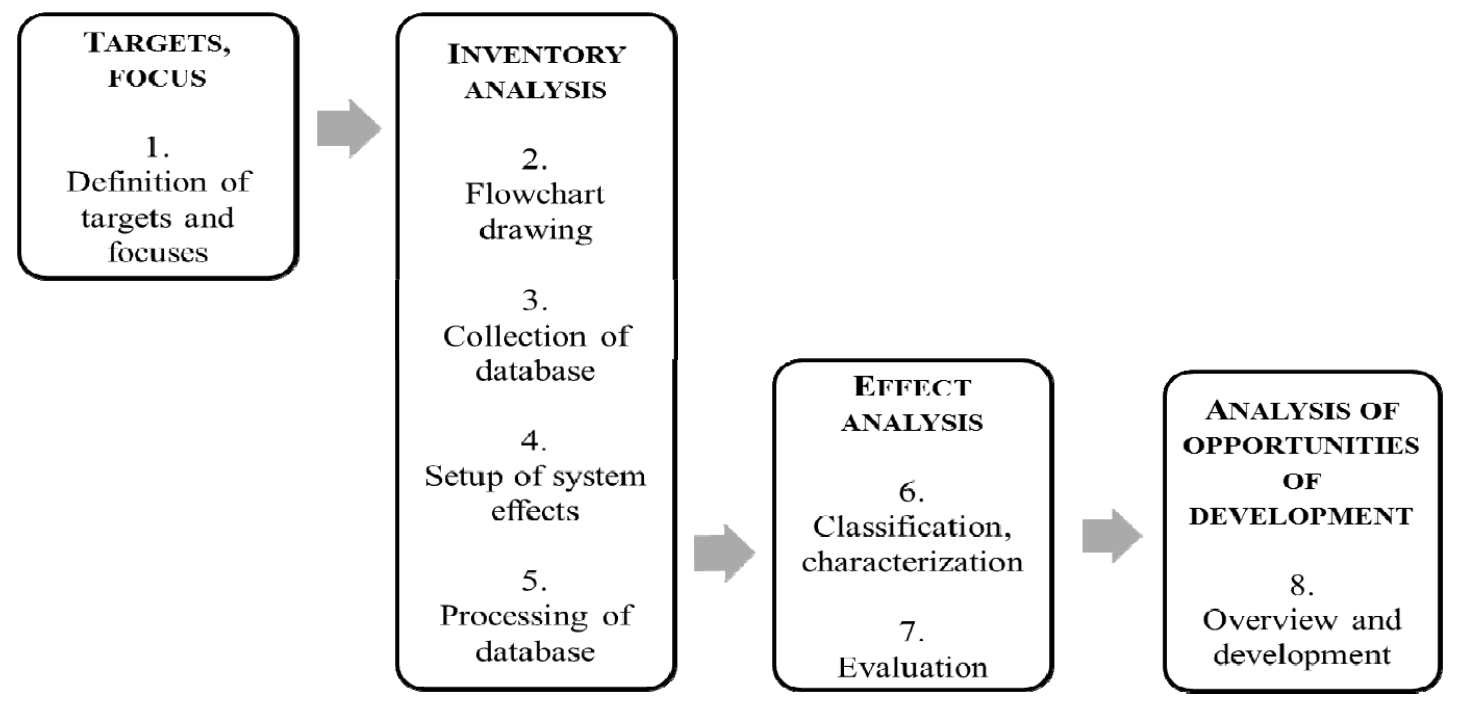

Source: ISO 14040

Using primary and secondary sources, the total production or service process should be prepared in relation of energy and material flow and balance and technical/technological parameters as well.

According to these, the data may have the following characteristics:

- technological representativeness,

- geographical representativeness,

- temporal representativeness,

- completeness,

- reliability. 
After weighting, normalization and classification, indicators may be formed as the results of the life cycle effect analysis. These indicators will agglomerate the long list resulted by the previous step. In this way the data and processes may be processed easier.

The target of the Inventory Analysis - as the second step of LCA - is the exploration of the cause and effect relations. Depending on which conditions and procedures were simplified during the data collection and processing, the individual factors may affect each other in different ways and extent. The sensitivity analysis is suitable for defining not only the degree but also the direction of the interaction. The importance of sensitivity analysis is outstanding because it helps to reduce the potential uncertainty which is derived from the use of estimations or approximations. (Sára, 2010)

By using life-cycle analysis (LCA) as the logical framework of the research can be determined (Figure 7), the examined variables can be specified so as to be adjusted to the research objectives. The optimization process may be realized by linear programming methods.

Figure 7: The logical framework of the life-cycle analysis of biomass energy

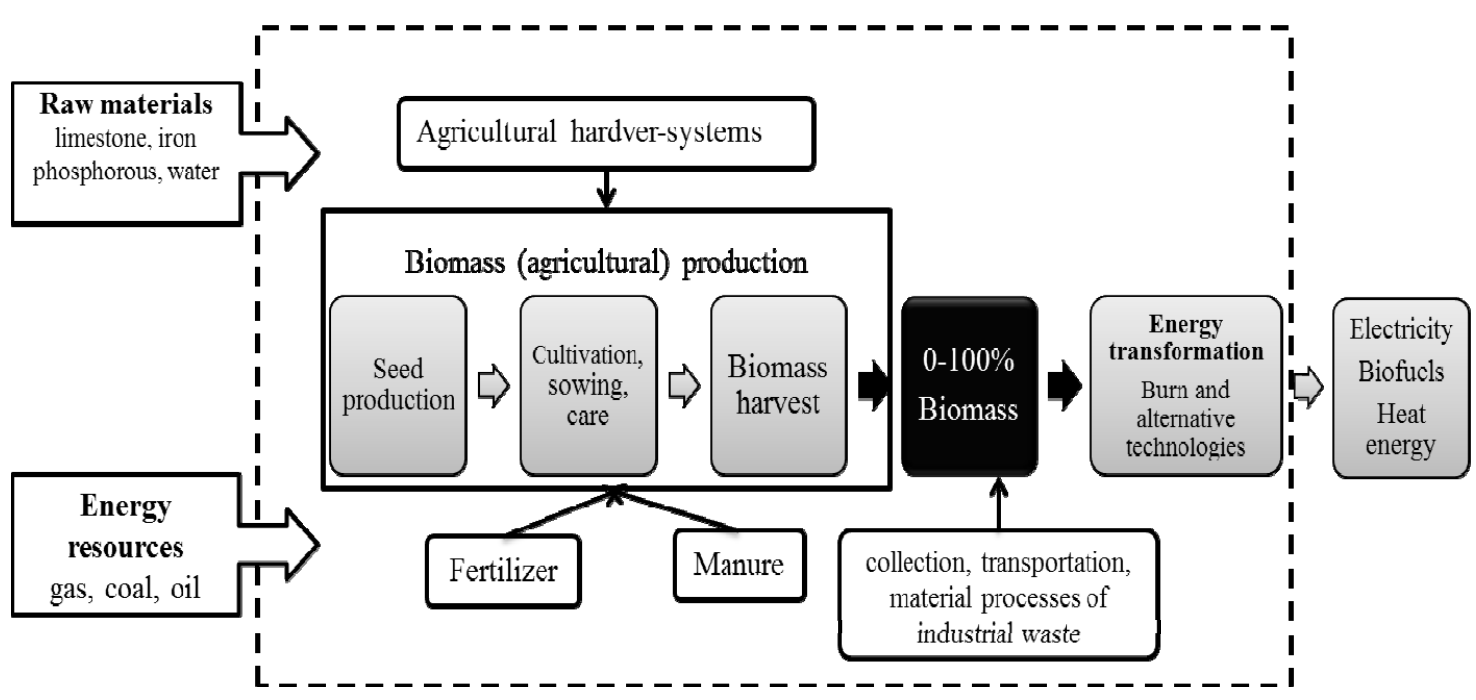

Source: own construction, based on Heller et al., 2004.

Linear programming, despite it uses many simplifying methods, is one of the most widely used method for optimization processes of complex agricultural systems. The objective functions of the optimization of biomass production are the following (Bedéné, 2011):

- available maximum income,

- maximum amount of the produced biomass,

- maximum amount of biogas originated from the produced biomass,

- maximum income originated from biogas production,

- maximum amount of bioethanol originated from the produced biomass,

- maximum income originated from bioethanol production, 
Vida, A. - Illés, B. Cs.

- maximum amount of biodiesel originated from the produced biomass,

- maximum income originated from biodiesel production.

The main deficiency of the abovementioned calculations is that it calculates with amounts and income values of field crop production, the different costs of energy production and the environmental effects are disregarded by the method.

As the data requirements of linear programming are very high, we considered choosing a simplified model for the examinations of the topic of this paper; therefore, we developed an expert system by using a pivot programming method. The data were accessed from the database of the Hungarian Statistical Office and other official agricultural databases.

Table 1: Changes of the cost items of plant growing in some European regions

\begin{tabular}{|c|c|c|c|c|c|c|c|}
\hline & \multirow[b]{2}{*}{ Unit } & \multirow[b]{2}{*}{$\begin{array}{l}\text { Percent } \\
\text { of Total } \\
\text { Cost }\end{array}$} & \multicolumn{5}{|c|}{ Cost (€/unit) } \\
\hline & & & $\begin{array}{l}\text { North } \\
\text { Europe }\end{array}$ & $\begin{array}{l}\text { Great } \\
\text { Britain } \\
\text { and } \\
\text { Ireland }\end{array}$ & $\begin{array}{l}\text { West } \\
\text { Europe }\end{array}$ & $\begin{array}{l}\text { South } \\
\text { Europe }\end{array}$ & $\begin{array}{c}\text { East } \\
\text { Europe }\end{array}$ \\
\hline Fertilizer $(\mathrm{N})$ & $\mathrm{kg}$ & 12,90 & 0,88 & 0,71 & 0,82 & 0,63 & 0,46 \\
\hline Fertilizer $(\mathrm{P})$ & $\mathrm{kg}$ & 1,70 & 1,21 & 0,71 & 1,33 & 0,67 & 0,55 \\
\hline Fertilizer $(\mathrm{K})$ & $\mathrm{kg}$ & 2,10 & 0,44 & 0,36 & 0,36 & 0,67 & 0,30 \\
\hline Glyphosate & 1 & 0,70 & 5,05 & 5,60 & 4,45 & 4,00 & 6,40 \\
\hline Labour & $\mathrm{h}$ & 21,70 & 18,13 & 16,00 & 17,00 & 8,00 & 3,80 \\
\hline Plowing & ha & 20,30 & 91,21 & 74,13 & 90,60 & 90,00 & 38,00 \\
\hline Spaying & ha & 20,30 & 14,29 & 17,30 & 13,18 & 14,00 & 6,50 \\
\hline Spreading & ha & 20,30 & 15,38 & 14,83 & 10,43 & 15,00 & 7,00 \\
\hline Cost level & & 100,00 & 100,00 & 93,70 & 89,2 & 83,20 & 41,30 \\
\hline
\end{tabular}

Source: Ericsson et al., 2009. p. 1581.

Because the short rotation energy plantations may be inserted into the micro economic calculations, it is necessary to know the most important characteristics of the different species. (see Table 2.)

Table 2: Some key indicators of short rotation wood fuel types

\begin{tabular}{|c|c|c|c|c|c|c|}
\hline \multirow[b]{2}{*}{ Plant } & \multicolumn{6}{|c|}{ Indicators } \\
\hline & $\begin{array}{l}\text { Energy } \\
\text { content } \\
(\mathrm{MJ} / \mathrm{kg})\end{array}$ & $\begin{array}{c}\text { Average } \\
\text { yield } \\
\text { (t/ha/year) }\end{array}$ & $\begin{array}{l}\text { Energy yield } \\
\text { (GJ/ha/year) }\end{array}$ & $\begin{array}{c}\text { Moisture } \\
\text { content }\end{array}$ & $\begin{array}{l}\text { Density } \\
\left(\mathrm{g} / \mathrm{cm}^{3}\right)\end{array}$ & Rotation \\
\hline Oak* & 11,5 & 2,6 & 2,6 & \multirow{8}{*}{0,4} & 0,69 & 106 \\
\hline Beech & 11,5 & 3,7 & 3,7 & & 0,68 & 100 \\
\hline Hornbeam & 11,5 & 2,5 & 2,5 & & 0,83 & 80 \\
\hline Acacia & 11,5 & 5,1 & 5,1 & & 0,77 & 30 \\
\hline Alder & 9 & 3,5 & 3,5 & & \multirow[t]{2}{*}{0,53} & 50 \\
\hline Lime & 9 & 3,5 & 3,5 & & & 50 \\
\hline Poplar* & 9 & 4,2 & 4,2 & & \multirow{2}{*}{0,50} & 47 \\
\hline Willow & 9 & 3,9 & 3,9 & & & 45 \\
\hline
\end{tabular}

* average of different types

Source: KvVm, 2007 
It can be seen that although most of the indicators of acacia seems to be the best, in terms of the rotation it would be the worst choice. The number of rotation is an important point of view during the income maximization, that is why the beech could be the optimal choice. As a normative economic criterion, the ability of the soil conditions is accepted for both types of wood.

\section{Results and discussion}

In our research, the basic criteria of linear programming were used, but the criteria (attributes) used in our calculations were fixed in contrasts with the LP models. The possible objects of the research were compared by the using these attributes, which were fixed on the basis of natural units or a 10-point scale (Table 3).

Table 3: Objects and attributes of the research

\begin{tabular}{|l|l|}
\hline \multicolumn{1}{|c|}{ Objects (rows) } & \multicolumn{1}{c|}{ Attributes (columns) } \\
\hline BAU corn & $\begin{array}{l}\text { Price of raw materials }(\mathrm{HUF} / \mathrm{ha}) \\
\text { Income from by-products }(\mathrm{HUF} / \mathrm{ha}) \\
\text { Average yield }(\mathrm{t} / \mathrm{ha})\end{array}$ \\
\hline BAU rapeseed & $\begin{array}{l}\text { Amount of fertilizers needed }(\mathrm{kg} / \mathrm{ha}) \\
\text { Amount of used water }\left(\mathrm{m}^{3} / \mathrm{ha}\right)\end{array}$ \\
\hline SUS corn & $\begin{array}{l}\text { Usability of biomass }(10-\text { point scale) } \\
\mathrm{CO}_{2} \text { burden }(10 \text {-point scale) }\end{array}$ \\
\hline SUS rapeseed & Need for additional investment $(\mathrm{HUF} / \mathrm{ha})$ \\
\hline BAU corn + energetical wood fuel & \\
\hline BAU rapeseed + energetical wood fuel &
\end{tabular}

Variations of raw material production: BAU - Business As Usual; SUS - SUStainable

Source: own construction, 2013

According to the results, in that case where the quality of raw materials produced by sustainable methods is not incorporated in the price of the product, the use of conventional crop production methods is suggested. Nevertheless, if the use of sustainable production method is not expressed by the product price, there could be another opportunity for compensation, by the selling the $\mathrm{CO}_{2}$ quota savings, but its conditions are not available in Hungary by now.

Table 4: The results of calculations of expert system

\begin{tabular}{|l|c|c|c|}
\hline \multicolumn{1}{|c|}{ Objects (rows) } & Efficiency & $\begin{array}{c}\text { Self- } \\
\text { production }\end{array}$ & Sustainability \\
\hline BAU corn & $\checkmark(1)$ & & \\
\hline BAU rapeseed & & $\checkmark(2)$ & \\
\hline SUS corn & & & \\
\hline SUS rapeseed & & $\checkmark(3)$ \\
\hline $\begin{array}{l}\text { BAU corn + energetical wood } \\
\text { (for heat energy) }\end{array}$ & & $\checkmark(4)$ & \\
\hline $\begin{array}{l}\text { BAU rapeseed + energetical wood } \\
\text { (for heat energy) }\end{array}$ & & & \\
\hline
\end{tabular}

Variations of raw material production: BAU - Business As Usual; SUS - SUStainable

Source: own construction, 2013 
Vida, A. - Illés, B. Cs.

After the comparison of the conventional agricultural production systems (BAU) we can make the following statements:

- According to the general economic aspects, corn production means the more favourable option, because of the different selling opportunities - e.g. food, energy production, material for food processing may decrease the risks of the producers.

- When the self-supporting character of agricultural production is preferred, the production of rapeseed is suggested. The investment needed for oil pressing can be covered by machinery investment supports. Diesel engines used in Hungary may also be operated by pressed and cleared vegetable oil; vegetable oils can be sold either for human consumption or for biodiesel production.

- Esterification process is not suggested because its technology needs high investment costs. As the biodiesel market is very unstable, the returns may bring an additional burden for the producers.

- The abovementioned issues are similar in bioethanol production.

- Sustainable biomass energy production may be improved by supplementing the present crop structure by short rotation coppice. In this case, the quality of the soil should also be taken into consideration. The soil demand of energy woods is similar to fieldcrops, therefore it requires a long-term use of cropping area, longterm planning of rotation and nutrient supply.

- If we accept the introduction of energy wood, the machinery used in corn production may be used in harvesting, therefore additional costs should not be calculated.

\section{Conclusion}

The European Union has introduced several directives and objectives in connection with the energy sector in the past decades, while the Common Agricultural Policy has also undergone remarkable changes.

The use of renewable energy sources may be considered as the cross section the energy sector and agriculture, not only new solutions but also new challenges are brought by the use of renewable energy sources for all member states. Renewable energy sources became a promising topic with many direct and indirect advantages for policy makers, but only few member states could fulfil their targeted share of renewable energy sources by 2010 . As the EU offered many supports and instructions, we may conclude that there is not a general method for being successful.

Positive effects of some activities need special strategy and special measures; it is quite true for the topic of our research, biomass production. For the producers the most important issues are coming from the economic side, therefore yield losses derived from environment friendly and sustainable production should be compensated. Without compensation - either in prices or in the $\mathrm{CO}_{2}$ quotas - the best solution is intensive field crop production, but ecologic issues should also be taken into consideration and some alternative methods should be developed for the realization of the concept of energetically self-supporting agricultural farms. 


\section{References}

1. AKI (2012): A beruházások és a pénzügyi mutatók várható alakulása a mezőgazdaságban 2011-ben. Budapest. Access at:

https://www.aki.gov.hu/publikaciok/dokumentum/f:9520//Mezőgazdasági+beruházások+ várható+alakulása+2011.év (2012.07.01.)

2. Ángyán, J.; Balázs, K.; Nagy, G. (2006): Fenntartható és többfunkciós mezőgazdaság. Környezetvédelmi Füzetek, ELGOSCAR-2000 Környezettechnológiai és Vízgazdálkodási Kft., Budapest

3. Barótfi, I.; Bartha, I.; Bálint, I.; Beke, J.; Gabai, L.; Kapros, T.; Jászai, T. (1993): Energiafelhasználói kézikönyv. Környezet-technika Szolgáltató Kft. Budapest

4. Bedéné Szőke, É. (2011): Vállalati szintü biomassza termelés optimalizálása. Doktori értekezés, Szent István Egyetem, Gödöllő

5. Borchers, A. M.; Duke, J. M.; Parsons, G. R. (2007): Does willingness to pay for green energy differ by source? Energy Policy, Elsevier, Vol. 35., pp. 3327-3334.

6. Boros, T. (2007): Benzin száz forinttal olcsóbban - avagy az energiaetanol gyártásának gazdaságossági kérdései. Környezetvédelmi Füzetek 2007/3. Budapest, ELGOSCAR2000 Környezettechnológiai és Vízgazdálkodási Kft.

7. Büki, G. (2007): A biomassza energetikai hasznosítása III. - Bioenergia. Múegyetemi Kiadó, Budapest, pp. 3-6.

8. EEA (2006): How much bioenergy can Europe produce without harming the environment.. EEA Report

9. Ericsson, K.; Rosenquist, H.; Nilsson, L. J. (2009): Energy crop production costs in the EU. Biomass \& Energy, Elsevier, Vol. 33., pp. 1577-1586.

10. GreenPeace (2011): Progresszív Energia (Forradalom): A fenntartható energiagazdálkodás lehetőségei Magyarországon. (Magyarországi energiapolitikai forgatókönyv, 2. kiadás) Greenpeace International - Európai Megújuló Energia Tanács (EREC) Access at: http://greenpeace.hu/up_files/1321950799.pdf (2012.06.10.)

11. Hancsók, J. (2004): Korszerü motor- és sugárhajtómü üzemanyagok. III. Alternatív motorhajtóanyagok. Veszprémi Egyetemi Kiadó, Veszprém

12. Heller, M.C.; Keoleeian, G. A.; Mann, M. K.; Volk, A. T. (2004): Life cycle energy and environmental benefits of generating electricity from willow biomass. Renewable Energy, Elsevier, Vol. 29., pp. 1023-1042.

13. Hungarian Action Plan (2010): Action Plan for Using Renewable Energy Sources to 2020 in Hungary. Access at:

http://www.kormany.hu/download/2/88/20000/NCsT_20110106_v\%C3\%A9gleges_2011 03.pdf (2010.10.15.)

14. Hungarian Strategy (2008): Hungarian Strategy for Increasing Use of Renewable Energy Sources between 2008 and 2020. Access at http://www.nkek.hu/ext/download.php?id=145 [2010.10.15.]

15. Illés, B. Cs.; Dunay, A.; Vida, A. (2013): Position of Hungary on EU's Map of Renewable Energy Soruces In: Dermol, Trunk Sirca, Dakovic (eds.) Management, Knowledge and Learning (MakeLearn) International Conference 2013, CD Proceeding, pp. 1397-1405.

16. Ivelics, R. (2005): in Barkóczy, Zs.; Ivelics, R. (2008): Energetikai célú ültetvények. Erdészeti kisfüzetek, Sopron, Access at: http://www.emk.nyme.hu/fileadmin/dokumentumok/emk/moi/PolitikaEsOkonomia/Kiadv anyok/EnergetikaiCeluUltetvenyek.pdf (2013.04.12.)

17. KvVM (2007): Klímapolitika - A biomassza energetikai alkalmazásának jövője, aktuális problémái. Környezetvédelmi és Vízügyi Minisztérium, Budapest 
Vida, A. - Illés, B. Cs.

18. Láng, I.; Harnos, Zs.; Csete, L.; Kralovánszky, U. P.; Tőkés, O. (1985): A biomassza komplex hasznosításának lehetőségei. Mezőgazda Kiadó, Budapest

19. Lukács, G. S. (2009): Megújuló energia és vidékfejlesztés. Szaktudás Kiadó Ház, Budapest

20. Marjainé, Sz. Zs. (ed.) (2005): A természetvédelemben alkalmazható közgazdasági értékelési módszerek

21. Menegaki, A. (2008): Valuation for renewable energy. Renewable and Sustainable Energy Reviews, Vol. 12. pp. 2422-2437.

22. Pylon Kft. (2010): Magyarország 2020-as megújuló energiahasznosítási kötelezettségvállalásának teljesítési ütemterv javaslata. (Alapkutatások a Nemzeti Megújuló Energiahasznosítási Cselekvési Tervhez); Access at:

http://etanol.info.hu/download/meh_pylonc_4.pdf ; (2013.03.10.)

23. Sára, B. (2010): Az életciklus felmérés lépései.

enfo.agt.bme.hu/drupal/sites/default/files/LCA\%20lépései_0.pdf (2013.01.10.)

24. Stróbl, A. (2000): A biomassza erőmüvi és fütőművi hasznosításának gazdaságossága a fejlett országokban. OMIKK, Budapest

25. Törö-Dunay, A. (2011): Development of Rural Areas through CAP 2020 and Europe 2020 Strategy. Scientific Journal of Warsaw University of Life Sciences - SGGW Problems of World Agriculture, Volume 11 (XXVI) 2011. Number 3., pp. 161-169. 